\title{
A DISPUTA E A SUB-REPRESENTAÇÃO DAS MULHERES NOS ESPAÇOS DE PODER: O CASO DA ASSEMBLEIA LEGISLATIVA DA PARAÍBA
}

\author{
Elizabeth Christina de Andrade Lima ${ }^{1}$ \\ Ana Paula Guedes do Nascimento ${ }^{2}$ \\ Carolina de Moura Cordeiro Pontes ${ }^{3}$
}

- Enviado em 11/04/2016

- Aprovado em 20/05/2016

\section{RESUMO}

$\mathrm{O}$ advento da participação de mulheres na política suscita alguns pontos para reflexão. A trajetória enfrentada por mulheres a fim de conquistar o espaço público e deixar a condição de subordinada à esfera privada e do lar, as dificuldades e preconceitos ainda enfrentados para a instituição de posições dentro da prática política e a ineficácia da Lei de Cotas, são alguns dos aspectos que merecem ser discutidos quando se trata da disputa das mulheres por espaços de poder. Desse modo, este artigo centra suas análises na reconstrução do percurso histórico e cultural realizado pelas mulheres no que diz respeito a sua participação em espaços de liderança e de política, na estruturação do campo político e da Lei de Cotas e, sobretudo, na análise de uma possível relação entre a "condição de gênero" a partir da atuação parlamentar das três representantes femininas da Assembleia Legislativa do Estado da Paraíba, eleitas na Campanha de 2014. A construção da análise aqui proposta se deu a partir de dados coletados no ciberespaço, especialmente redes sociais, como o Facebook e do acompanhamento das principais reportagens publicadas nos sites e blogs locais, referentes às atividades e ações públicas das referidas deputadas.

Palavras-chave: Mulher e Política, Gênero, Lei de Cotas, Legislativo.

\footnotetext{
1 Graduada em Ciências Sociais pela UFPB, Mestre em Sociologia Rural pela UFPB, Doutora em Sociologia pela UFC, Professora de Antropologia Associado IV da UFCG. Endereço eletrônico: ecalima@terra.com.br

${ }^{2}$ Graduada em Ciências Sociais pela UFCG, Mestranda em Ciências Sociais junto ao PPGCS/UFCG. Endereço eletrônico: a.paulagnc@gmail.com
}

${ }^{3}$ Graduada em Direito pela UNICAP, Mestre em Ciências Sociais pelo PPGCS/UFCG, Doutoranda em Ciências Sociais junto ao PPGCS/UFCG. Endereço eletrônico: carolinademouracp@ hotmail.com 


\section{INTRODUÇÃO}

A presença de mulheres na vida pública tem, ao longo dos anos, se tornado uma realidade. A ruptura com alguns dos papeis e lugares estabelecidos por uma sociedade mesmo ainda marcada pelas práticas sexistas e patriarcais, como os únicos legítimos e adequados à presença feminina, tem proporcionado o alcance de setores da sociedade que até poucas décadas atrás, eram completamente renegados às mulheres, a exemplo da política.

A disputa das mulheres nos espaços de poder vem, ao longo dos anos, despertando o interesse de pesquisadores das mais variadas áreas das chamadas Ciências Humanas e Sociais. O advento da participação de mulheres na política suscita algumas particularidades e questionamentos que merecem e necessitam de problematização e investigação científica. A trajetória percorrida pelas mulheres a fim de conquistar o espaço público e deixar a condição de subjugada à esfera privada e do lar, as formas e os meios de inserção utilizados para adentrarem em tais espaços, as dificuldades, obstáculos e preconceitos ainda enfrentados para a instituição de posições na atividade política, a relação entre a "condição de gênero" e a prática política, o fato de, apesar dos avanços e conquistas, a presença destas nesses espaços de poder e decisão, ainda representarem números de pouca expressão e a consequente ineficácia da Lei de Cotas, são alguns dos aspectos observados, questionados e discutidos no que se refere à participação de mulheres na vida pública e política.

É baseada em alguns desses questionamentos que este artigo tem como objetivo apresentar alguns resultados quanto à presença e participação de mulheres na Assembleia Legislativa da Paraíba, bem como a atuação destas em suas atividades parlamentares. Interessa-nos obsevar se nas referidas atuações a questão de gênero e uma pauta dirigida as demandas femininas estão contempladas, e quais seriam tais demandas.

Para tanto, o artigo centra suas análises na reconstrução do percurso histórico e cultural realizado pelas mulheres no que diz respeito a sua iniciação na vida pública e política, na estruturação do campo político e da Lei de Cotas e, sobretudo, na análise de uma possível relação entre a "condição de gênero" e a atuação enquanto mulheres parlamentares. Buscamos coletar diferentes materiais de informações sobre as atuais deputadas estaduais da Paraíba: Daniella Ribeiro (PP), Camila Toscano (PSDB) e Estelizabel Bezerra (PSB) em fontes como: reportagens publicadas nos sites e blogs estaduais referentes às suas atuações, o acompanhamento de suas falas, através de contas pessoais em redes sociais, tais como o Twitter e o Facebook e o levantamento de suas atuações parlamentares, por meio da análise de suas proposituras, requerimentos e projetos de Lei encaminhados à Assembleia. 


\section{A INSERÇÃO DE MULHERES NOS ESPAÇOS DE PODER E A LEI DE COTAS}

A discussão sobre a participação das mulheres nos espaços de poder implica diretamente numa reconstrução histórica, social e cultural da própria política brasileira. Necessário se faz notarmos que a ascensão destas ao meio político resulta de uma, às vezes árdua e longa trajetória do espaço privado ao espaço público. (COELHO \& BAPTISTA, 2009).

$\mathrm{Na}$ época do Brasil Império, a mulher brasileira era vista sob a ótica da cultura europeia; estava ela ainda inserida em uma estrutura de subordinação e restrita às atividades domésticas. Sob a forte influência do sistema patriarcal, foram poucas as que durante esse período lutaram por seus direitos e emancipação. (BATISTA, 2008)

Um pouco mais tarde, uma mulher chama a atenção e passa a ser considerada como a primeira feminista brasileira, Nísia Floresta. Ela nasceu em 12 de outubro de 1810 e vive em meio a um contexto rigidamente patriarcal por isso, lutará incansavelmente pelo acesso à capacitação intelectual das mulheres e de seu direito à educação formal. A autora teve seus escritos conhecidos por reivindicar o direito de envolvimento das mulheres em outros temas e debates políticos. Apesar de ser considerada por vezes conservadora, já que reafirmava muitos dos valores tradicionais consolidados, como por exemplo, a associação das mulheres às tarefas domésticas e aos cuidados com os filhos, Nísia Floresta tinha como objetivo, à sua maneira, subverter a ordem, apontando a "possibilidade de alterar a hierarquia de poder presente nas relações entre os sexos. Segundo a autora, exercendo sua influência sobre os homens, as mulheres podiam não só educá-los, mas também 'regenerá-los"”. (PRADO \& FRANCO, 2003, p. 207).

Com o advento da modernidade, a crescente industrialização e a estruturação da família burguesa, ocorreram mudanças significativas nos papeis de gênero. Tais modificações puderam ser observadas no Brasil a partir do século XIX. Assim, couberam as mulheres a responsabilidade pela educação dos filhos, os cuidados com a casa e até mesmo a transmissão de valores. Esse tipo de estrutura, que designou às mulheres todas as funções de domínio privado, possibilitou aos homens o envolvimento com as esferas políticas e econômicas, próprias do domínio público. 
A partir da década de 1860 a atividade filantrópica passou a ser encarada como um meio para as mulheres das classes mais abastadas afastarem-se das limitações impostas pelo trabalho doméstico. À época, como destacam Coelho e Baptista (2009), iniciam-se as argumentações em torno das ideias abolicionistas, "onde muitas mulheres contribuíram com atividades para esses fins, embora 'não em posição política'”. (COELHO \& BAPTISTA, 2009, p. 85).

A participação destas no movimento restringia-se a angariação de fundos, ficando dessa forma, excluídas dos debates políticos sobre emancipação. É importante destacarmos que, ainda hoje, é comum as mulheres iniciarem suas atividades na vida pública através do envolvimento em projetos e trabalhos de cunho social. Este é um papel frequentemente exercido pela denominada "primeira-dama", sobretudo, àquela que almeja exercer um cargo público.

A transição do século XIX para o século XX proporcionou diversas discussões que buscavam explorar as variadas concepções de um novo papel feminino na sociedade brasileira. Em 1891 é elaborada a primeira Constituição Republicana Brasileira. A mesma debateu e vetou o sufrágio feminino. "Os que argumentavam contrariamente se referiam, por exemplo, à inferioridade feminina, tida por alguns como "natural'”. (COELHO \& BAPTISTA, 2009, p. 88). As mulheres eram definidas como a "parte moral da sociedade", a base da família, na qual o lar, o casamento e a maternidade, estruturavam sua existência social, cabendo aos homens o desenvolvimento de suas possibilidades e ambições na vida pública.

Apesar do veto ao voto feminino na primeira Constituição, como um direito das mulheres, tal ideia não foi mais abandonada, ocasionando o surgimento do movimento sufragista no Brasil. Na Europa, o movimento já vigorava desde o fim do século XIX.

Bertha Lutz, bióloga reconhecida internacionalmente, tendo mais tarde se formado em Direito, se dedicou a tarefa de unir as mulheres em torno de uma "liga" na qual pudessem reivindicar por seus direitos políticos e por sua emancipação frente à dominação do sexo oposto. Assim, em 1922, Bertha organizou a "Federação Brasileira para o Progresso Feminino" (F.B.P.F), filiada à International Woman Suffrage Aliance (COELHO \& BAPTISTA, 2009, p. 89), que defendia os direitos políticos das mulheres e o sufrágio feminino. As autoras destacam que Bertha, assim como outras mulheres integrantes da Federação, pertenciam a uma elite econômica e intelectual, o que as permitia um acesso mais livre as figuras políticas de maior influência e a opinião pública como um todo. Desse modo, por influência da união de várias forças de luta em prol dos direitos femininos e principalmente da F.B.P.F, a Constituição de 1934, instituiu para as mulheres o direito de votar e ser votada. Já por força de um decreto de fevereiro de 1932, 
promulgado pelo Presidente Getúlio Vargas, a Assembleia Constituinte viu eleger-se a primeira Deputada Federal, a médica Carlota Pereira de Queiroz, pelo Estado de São Paulo.

Nesse percurso de conquistas e emancipação, alguns autores chamam a atenção para uma espécie de desmobilização, após a conquista do sufrágio universal, entre as décadas de 40 e 50 , período da Segunda Guerra Mundial, que implicou no retorno de mulheres às atividades domésticas e ao trabalho assalariado (dupla jornada de trabalho), devido à convocação de seus companheiros pelo Exército brasileiro.

A presença das mulheres na cena social brasileira é retomada a partir da década de 60 , com a intensificação da ditadura civil militar. Estas se fizeram presentes nos "movimentos populares de oposição, criando suas formas próprias de organização, lutando por seus direitos sociais, justiça econômica e democratização". (SOARES, 1998, p.34). As crises econômicas, a crescente inflação e o processo de abertura política, fizeram com que as décadas de 70 e 80 mobilizassem as classes médias e a classe operária. Durante a década de 70 o movimento de mulheres pôs nas ruas brasileiras que lutaram em defesa de seus direitos, necessidades e contra as desigualdades.

Os grupos feministas e movimentos de mulheres dos anos 70 e início dos anos 80, juntamente com as comemorações do Dia Internacional da Mulher, constituíram-se em períodos propícios para a organização de fóruns de mulheres e articulação de protestos públicos contra a discriminação de sexo. Com a reorganização partidária, a mulher feminista adentrou os partidos e colocou as questões femininas como centro do debate, item obrigatório nos programas e plataformas eleitorais, fato este garantido pela visibilidade alcançada pela participação nos movimentos.

Os anos 80 ficaram marcados ainda pelas novas formas de organização e instituição de ações voltadas para o corpo, a saúde, a sexualidade feminina e o combate à violência. Os anos 90 promoveram a ampliação em torno dos direitos e emancipação feminina, instituindo ações afirmativas, as cotas mínimas de mulheres nos sindicatos, partidos políticos e nas candidaturas aos cargos legislativos.

Nesse contexto de conquistas e autonomia feminina, foi estabelecida no ano de 1997, a Lei $n^{\circ}$ 9.504, que assegura uma cota mínima de 30\% e uma cota máxima de $70 \%$ para cada um dos sexos, se estendendo para cargos eleitos por voto proporcional (Câmara dos Deputados, Assembleias e Câmara Distrital). Em 1995, a Lei n 9.100 estabelecia uma cota mínima de $20 \%$ para mulheres. A Lei de Cotas de 1997 pode ser pensada como uma política de ação afirmativa que reconhece a sub-representação da mulher nos espaços de poder em decorrência de dominação 
masculina que no Brasil é histórica, portanto a Lei de Cotas é concebida, também, como uma lei compensatória:

No caso das cotas eleitorais por sexo, esta ação afirmativa busca criar condições para o estabelecimento de um maior equilíbrio entre homens e mulheres no plano da representação política. Num primeiro momento, são medidas compensatórias que possibilitam que mais mulheres ocupem espaços. Num segundo, são medidas distributivas que buscam assegurar a igualdade entre homens e mulheres. (GROSSI \& MIGUEL, 2001, p. 169)

Dados recentes, divulgados pela União Inter-Parlamentar (UIP), apontaram que num total de 190 países, o Brasil ocupa apenas a $116^{\mathrm{a}}$ posição no ranking de representação feminina no Legislativo. $\mathrm{O}$ estudo considerou as informações fornecidas pelo poder legislativo até primeiro de janeiro de 2014 (legislatura anterior), quando a Câmara era ocupada por 45 deputadas (9\%) e o Senado por 10 senadoras (13\%). Na atual legislatura, elas passaram a ser 51 deputadas $(9,9 \%)$ de um total de 513. E das 81 cadeiras do Senado, 12 são ocupadas por representantes femininas (pouco mais de 13\%). A média mundial de representação feminina no Legislativo é de $22,1 \%$, dado que evidencia a baixa presença de mulheres no parlamento brasileiro. Nesse sentido, alguns autores têm discutido as razões pelas quais a Lei de Cotas para a representação feminina na política, não tem alcançado os resultados esperados, após mais de 15 anos de sua implantação. Algumas publicações apresentam certo consenso e apontam três tipos principais de fatores que poderiam influenciar nas chances e decisões das mulheres se candidatarem, seriam estes de cunho socioeconômico, cultural e político;

Os culturais destacam os valores mais gerais que influenciam uma dada sociedade, bem como uma cultura de gênero mais ou menos igualitarista (NORRIS, 1993). Os socioeconômicos remetem a alguns indicadores, como escolaridade, renda e emprego. Já a dimensão política é tratada mais do ponto de vista das instituições partidárias e eleitorais e dos tipos de sistemas de representação (JONES, 2008). (ARAÚJO, 2009, p. 25)

Os autores acima citados suscitam a reflexão de não haver consenso quanto ao peso de cada um desses fatores no que se refere às chances e disposição de mulheres disputarem um cargo no Legislativo, embora haja o reconhecimento de que existe uma espécie de interdependência na composição de cada um dos fatores apresentados.

Outro importante elemento quanto à rentabilidade da Lei de Cotas, é a deficiência na fiscalização e a inexistência de sanções para punir os partidos que não cumprem os percentuais exigidos pelo dispositivo da Lei. Desse modo, os partidos por vezes burlam a efetividade da Lei 
empregando o artifício de montarem chapas de chamadas "candidaturas laranja". Estas são inscritas e lançadas sem o necessário preparo de seu representante ou marketing eleitoral, impossibilitando, assim, a esperada vitória eleitoral da pleiteante. Muitas vezes essas "candidaturas laranja" objetivam, na verdade, realizar uma espécie de manobra para o preenchimento mínimo de candidaturas exigidas por sexo.

Dados do Tribunal Superior Eleitoral (TSE), referentes às eleições do ano de 2014, apontam que a cada dez deputados eleitos, apenas um é do sexo feminino. Dos 1059 deputados estaduais eleitos no referido ano, apenas 121 são mulheres, 11,4\% do total. Apesar da baixa representação feminina nos números gerais das eleições estaduais, todos os Estados elegeram uma representante do sexo feminino para suas Assembléias. O Estado com o maior percentual de eleitas foi o Amapá, com 33,3\% (08 mulheres, num total de 24 deputados). Mato Grosso e Amazonas foram os Estados com menos eleitas, apenas 4,2\% em cada Estado (01 mulher entre 23 deputados). Nesse mesmo ano, é necessário ressaltar que cinco Estados não elegeram nenhuma mulher como representante para a Câmara dos Deputados, entre eles está à Paraíba, que teve suas 12 vagas ocupadas apenas por representantes do sexo masculino.

A fim de garantir maior eficácia às prerrogativas dispostas pela Lei de Cotas, a bancada feminina da Câmara dos Deputados, a partir de acordo feito com lideranças partidárias, apresentou Proposta de Emenda à Constituição (PEC), que foi votada no dia 16 de junho de 2015, com um texto base que buscava a destinação de $10 \%$ das vagas de cada coligação partidária para mulheres. A proposta inicial tinha como objetivo a destinação de $30 \%$ dessas vagas para mulheres, no entanto, após o enfrentamento de muita resistência por parte dos partidos maiores, foi acordado que este percentual ficaria nos 10\%. A cota além da Câmara dos Deputados, englobaria também os legislativos estaduais e municipais. A proposta tem como objetivo central, garantir através da Lei, a seguridade da participação feminina nos parlamentos, que hoje encontra-se em torno desse percentual. Promulgar tal lei implica na instituição da presença feminina nos espaços de poder e de decisão, e garante que não haja retrocessos e diminuição dessa representatividade.

A referida votação não atingiu o número de votos suficientes para ser aprovada, seriam necessários 308 votos e a emenda obteve 293. A votação foi marcada por discursos que evidenciam os obstáculos que são impostos as mulheres na forma de machismo, seja ele velado ou explícito. Segundo reportagem publicada pelo portal online El País, no dia 17 de junho de 2015, os deputados que se puseram a favor da emenda, utilizaram os seguintes argumentos. "Um deles afirmou que seria a favor da proposta porque o Plenário ficaria mais bonito". Outro ainda afirmou que a 
aprovação seria "importante por dar um voto de confiança às mulheres". Os contrários a proposta a descreveram como "injusta” por não considerar o mérito dos eleitos.

Sobre esta votação, propomos uma digressão, para relatarmos um pouco esse que deveria ter sido um dia histórico para o empoderamento das mulheres na disputa por espaços de poder.

\section{2. “O DIA DO EMPODERAMENTO FEMININO”: LUTAS E CONFRONTOS POR ESPAÇOS DE PODER}

A primeira tentativa de incentivar a participação das mulheres na política foi a cota percentual mínimo de 30\% - imposta aos partidos políticos, no momento de ofertar as candidaturas, através da Lei de Cotas, promulgada no ano de 1997.

Após quase dez anos de vigência das "cotas de mulheres para os partidos", observou-se ineficaz a medida, considerando a (manutenção da) mínima participação feminina nas cadeiras de vereadoras e deputadas no País.

Desde 2007, tramita no Congresso Nacional a Proposta de Emenda Constitucional, inicialmente conhecida como "PEC da infidelidade partidária" que pretendia regulamentar os mandatos e as trocas de partidos ocorridas durante a legislatura.

Durante o trâmite, tal PEC sofreu emendas, sendo, ainda, apensada a diversas outras PEC's, recebendo, finalmente, a "alcunha" de "Reforma Política", em que se passou a rever o sistema de votação proporcional e majoritário vigente no País. Aproveitando o ensejo, a bancada feminina propôs a cota de 10, 12 e 15\% de vagas de senadores, deputados e vereadores para as mulheres, respectivamente e progressivamente na primeira, segunda e terceira legislaturas. ${ }^{4}$

No dia 16 de junho de 2015, esta emenda aglutinativa foi votada pela Câmara dos Deputados. Dos 308 (trezentos e oito) votos necessários para a aprovação, 293 (duzentos e noventa e três) votos foram obtidos, sendo, portanto, rejeitada a proposta.

$\mathrm{Na}$ sessão estavam presentes 448 (quatrocentos e quarenta e oito) parlamentares. O Presidente da Câmara dos Deputados, Eduardo Cunha - PMDB, invocou o art.17 do Regimento

\footnotetext{
${ }^{4}$ Emenda aglutinativa nº57 da PEC 182/2007. Disponível em http://www.camara.gov.br/proposicoesWeb/prop mostrarintegra?codteor=1349292\&filename=EMA+57/2015+\%3D $\%$ 3E+PEC+182/2007. Acesso 13.março.2016.
} 
interno que impede o Presidente de proferir voto. Restaram 447 (quatrocentos e quarenta e sete) votantes.

Dos 447 (quatrocentos e quarenta e sete) votantes, 53 (cinquenta e três) se abstiveram de votar, 293 (duzentos e noventa e três) votaram a favor e 101 (cento e um deputados) foram contrários à reserva de vaga, na Câmara dos Deputados, Assembleias Legislativas e Câmara dos Vereadores, para as mulheres. Catorze votos a mais seriam suficientes para a aprovação. Em termos gráficos, podemos assim representar o resultado da votação:

Gráfico 1 - Resultado da eleição por voto

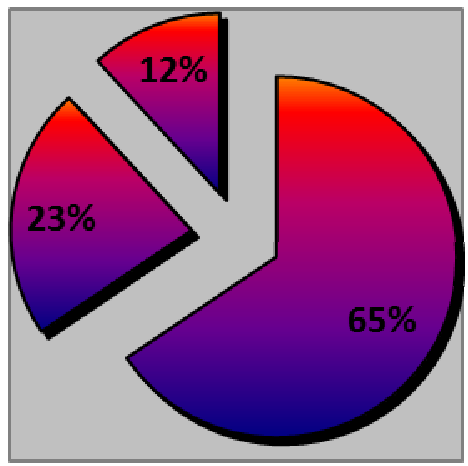

$$
\begin{aligned}
& \text { 口sIm } \\
& \text { 口não } \\
& \text { 口abstenção }
\end{aligned}
$$

Das 51 (cinquenta e uma) parlamentares eleitas para a Câmara dos Deputados nesta legislatura, estavam presentes à sessão 39 (trinta e nove) parlamentares, 12 (doze) ausentes, portanto. No mínimo curioso, foi observado que a deputada Magda Mofatto (PR-GO) votou contrariamente à proposta. Analisando o voto de homens e mulheres, teríamos o seguinte gráfico:

Gráfico 2 - Voto Feminino e Voto Masculino 


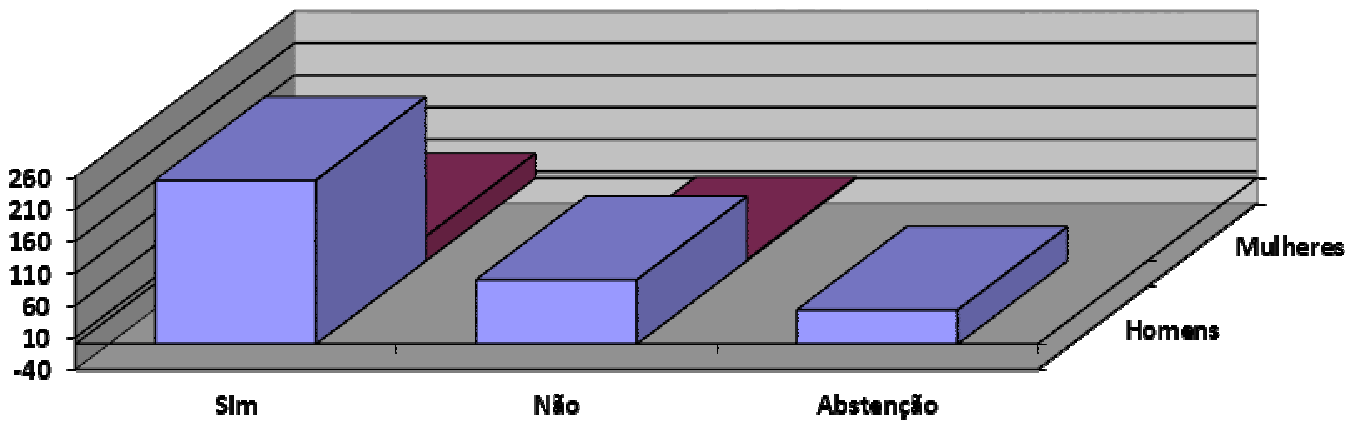

Outra questão curiosa identificada foi o fato de que antes da votação, os líderes de partidos se pronunciam para orientar o voto de seus correligionários. NENHUM partido orientou seus integrantes a votarem "não". Mesmo assim, foram 101 (cento e um) votos contrários à aprovação da proposta. A orientação foi pelo voto liberado (livre consciência do parlamentar) ou pelo voto "sim" (a favor da proposta), conforme se transcreve abaixo:

PT, PSD, PR, PDT, PC do B, PPS, PV e PSOL -> SIM

Minoria, Solidariedade, PROS, PSB, DEM,

Bloco do PRB, PTN, PMN, PSDC, PRTB, PTC, PSL

Bloco do PMDB, PP, PTB, PSC, PHS, PEN

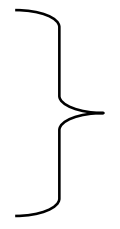

LIBERADO

Alguns partidos apresentaram homogeneidade no voto. $\mathrm{O}$ Partido Humanista da Solidariedade, composto por cinco deputados homens, foi o único, de maneira unânime, CONTRÁRIO à proposta.

Assim como o $\mathrm{PSL}^{5}, \mathrm{PTC}^{6}, \mathrm{PMN}^{7}, \mathrm{PEN}^{8}, \mathrm{PRTB}^{9}$, cada um composto por um parlamentar, $\mathrm{PSOL}^{10}$, composto por quatro parlamentares, $\mathrm{PV}^{11}$, composto de seis parlamentares, PPS ${ }^{12}$, composto por dez parlamentares e PC do B, composto por 11 parlamentares (presentes), em que TODOS foram FAVORÁVEIS à proposta.

\footnotetext{
${ }^{5}$ Partido Social Liberal Nacional.

${ }^{6}$ Partido Trabalhista Cristão.

${ }^{7}$ Partido da Mobilização Nacional.

${ }^{8}$ Partido Ecológico Nacional.

${ }^{9}$ Partido Renovador Trabalhista Brasileiro.

${ }^{10}$ Partido Socialismo e Liberdade.

${ }^{11}$ Partido Verde.

${ }^{12}$ Partido Popular Socialista.
} 
As três maiores bancadas da Câmara dos Deputados, PMDB, com 54 parlamentares, o PSDB, com 51 parlamentares e o PT, com 57 parlamentares presentes, assim votaram:

Gráfico 3 - Voto dos Partidos com maior número de presentes

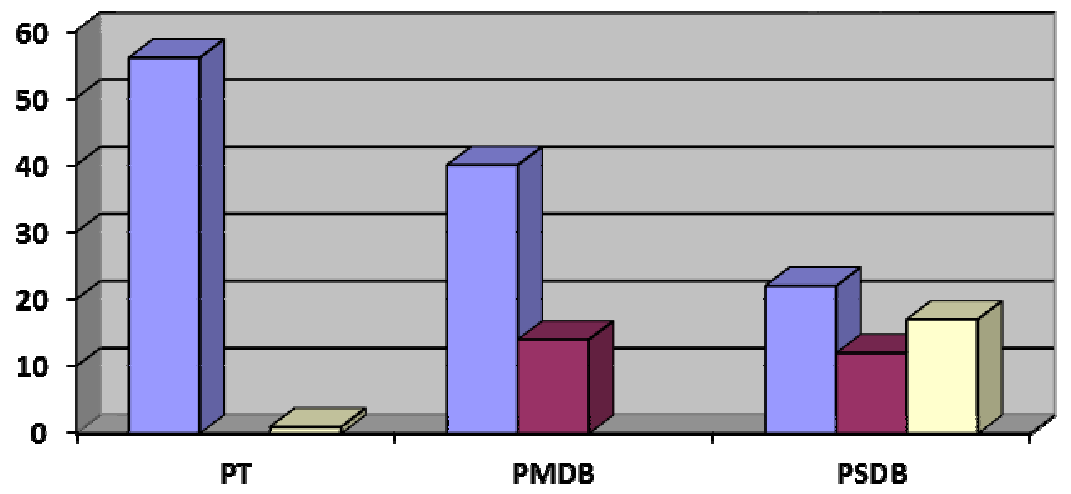

Outros partidos cujos votos mereceram destaque foram o PSB, com 30 parlamentares, PR, com 31 parlamentares, PP, com 32 parlamentares, PSD, com 29 parlamentares, PTB, com 21 parlamentares, PDT e DEM, com 18 parlamentares cada.

Gráfico 04 - Voto dos Partidos com número intermediário de presentes

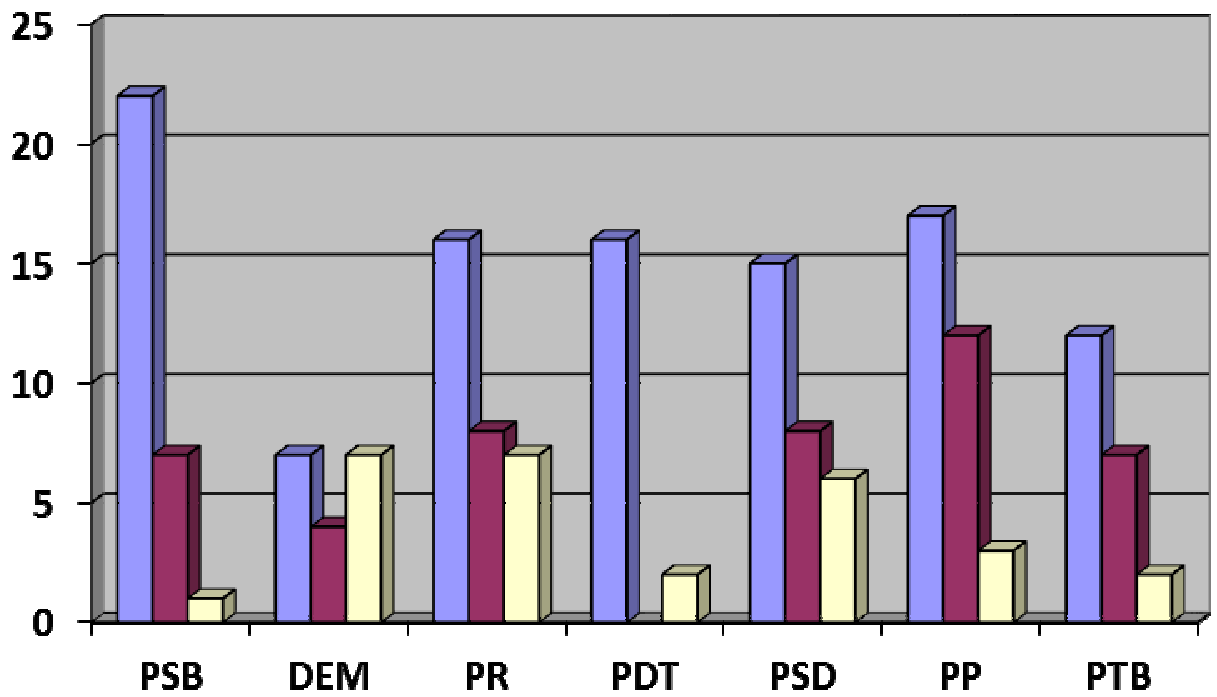

\begin{tabular}{|l|}
\hline 口Sim \\
口Não \\
पAbstenção
\end{tabular}

Numa votação em que o quórum para aprovação requerido é alto [eram necessários 308 votos], a abstenção do voto por 53 dos 447 presentes, cerca de 12\% (doze por cento), portanto, parece indicar uma resistência velada à aprovação das cotas. 
Partidos que se identificam como de orientação ideológica de esquerda apresentaram, com pouca divergência, grande número de votos favoráveis. Partidos que se identificam como de orientação ideológica de direita ou centro, apresentaram, com GRANDE DIVERGÊNCIA (houve votos contrários e abstenções), votos favoráveis à proposta. Nesse último caso, em alguns partidos, votos contrários e abstenções superam o número de votos favoráveis.

No sítio eletrônico da Câmara dos Deputados é possível encontrar toda a discussão da emenda aglutinativa $\mathrm{n}^{\circ} 57$, referente à PEC da reforma política. Discutiram a matéria a deputada Moema Gramacho (PT-BA), o deputado Glauber Braga do PSB-RJ, a Deputada Alice Portugal (PC do B-BA), Deputado João Rodrigues do PSD-SC, Deputada Carmem Zanotto (PPS-SC) e o Deputado Delegado Edson Moreira.

Segundo Raquel Paiva, o Brasil ocupa o $104^{\circ}$ lugar no mundo em representação feminina e na América Latina fica atrás do Haiti e Guatemala. Para Joaquim Barbosa Gomes, ex-Ministro do Superior Tribunal Federal, as ações afirmativas consistem em políticas públicas (e também privadas) voltadas à concretização do princípio constitucional da igualdade material e à neutralização dos efeitos da discriminação racial, de gênero, de idade, de origem nacional e de compleição física.

Dos seis discursos a serem analisados - deputada Moema Gramacho (PT-BA), Deputado Glauber Braga (PSB-RJ), Deputada Alice Portugal (PC do B-BA), Deputado João Rodrigues (PSDSC, Deputada Carmem Zanotto (PPS-SC) e Deputado Delegado Edson Moreira - dois foram contrários à implantação das cotas [Dep. João Rodrigues e Dep. Delegado Edson Moreira] - e quatro favoráveis [Dep.Moema Gramacho, Dep. Glauber Braga, Dep. Alice Portugal e Dep. Carmem Zanotto].

Vejamos enxertos dos discursos dos deputados que votaram favoravelmente:

É importante destacar que hoje apesar de sermos $52 \%$ da população, portanto mais da metade da população, e mãe da outra metade, ainda representamos simplesmente $10 \%$ dos legislativos em média. Isso é muito desproporcional. (...) Isso porque as mulheres só passaram a ter o direito a voto a partir de 1932 e mesmo assim de lá para cá nunca foram dadas as condições necessárias e as oportunidades para que as mulheres pudessem disputar em igualdade com os homens. (Deputada Moema Gramacho - PT-BA)

Se são $50 \%$ ou mais do que isso de mulheres na sociedade brasileira, ter uma representação no primeiro momento de $10 \%$, no segundo momento de $12 \%$ e no terceiro momento de $15 \%$ é o mínimo o que o parlamento brasileiro pode aprovar. (Deputado Glauber Braga - PSB-RJ) 
As mulheres do século XIX tinham que usar pseudônimos para poder assinar peças literárias e obras de arte. As mulheres só viraram cidadãs no Brasil em 1932. Mesmo assim com um voto que era facultativo e era facultado aos senhores pais e esposos dizer em quem se deveria votar (...) Portanto, essa Câmara de Deputados poderá, Senhor Presidente, dar sentido efetivo À reforma política, elevando a participação de $52 \%$ do eleitorado brasileiro, de $51 \%$ da população brasileira, as mulheres são maioria na universidade entre educadores, educandos, as mulheres são relevantes no Poder Judiciário, nas Polícias, e em todas as áreas da economia.(Deputada Alice Portugal - PC do B- BA)

Homens e mulheres que são responsáveis pela formação e legislação da nossa sociedade brasileira. Mulheres essas que já são responsáveis pelo sustento no seu município e nos seus domicílios, portanto, Senhor Presidente, nós precisamos sim de cotas e estamos pedindo as cotas" (...) Portanto, Senhor Presidente, quero aqui mais uma vez dizer que somos mais de $52 \%$ da representação do eleitorado brasileiro, $45 \%$ das mulheres estão no mercado de trabalho e não somos nem $11 \%$ que ocupamos o Legislativo, a Câmara dos Vereadores, as Assembleias e o Senado Federal. (Deputada Carmem Zanotto - PPS-SC)

Entre os discursos favoráveis, observamos, ainda, que as deputadas e o deputado esclareceram que embora as mulheres fossem mais de $50 \%$ da população, o sistema de cotas obrigava que, apenas, 10, 12 e 15\%, gradativamente na primeira, segunda e terceira legislaturas fossem implantados. Tratava-se, pois, de medida temporária, a viger durante doze anos e em índices muito abaixo da representatividade feminina na população.

Vejamos abaixo os dois discursos contrários;

Senhor Presidente, Senhoras e Senhores Deputados. O art.5 da Constituição diz que todos são iguais em direitos, independente de sexo e de cor. Portanto, Sr. Presidente não há uma injustiça na disputa sadia. Todos disputam o voto, todos trabalham para ser eleito. Não é justo,Senhor Presidente, que se dê uma parcela para que tal sexo, tal segmento tenha cotas para vir a Câmara, Senado ou Câmara vereadores ou Assembleias Legislativas. Não é justo. O certo é a disputa como é feita hoje. A disputa Sadia. Não tem desvantagem para nenhuma. Todo mundo vai a busca, vai a captura com seu trabalho, nas esquinas, nas favelas, no Brasil inteiro, no seu Estado por inteiro. Senhor Presidente, cotas daqui, cotas dali. Daqui a pouco, senhor Presidente, todos se passar, por exemplo, essa emenda, estarão fazendo cirurgias para mudar de sexo. Vai ficar muito fácil vir para a Câmara Federal com as cotas. A disputa tem que ser voto a voto. Trabalho a trabalho e não uma percentagem. Se não houvesse disputa, a disputa é igual para todos. Todos são iguais na disputa. Ganha quem for mais votado. Agora, se tiver cota, Senhor Presidente, vai ficar ruim. (Deputado Edson Moreira - PTN-MG)

(...) eu quero colocar minha posição como parlamentar, o porquê que eu não participo, não concordo com isso. Porque cada deputada que aqui está chegou pelo mérito de seu trabalho. Chegou porque trabalhou na sua base. Porque construiu uma história. Eu acho que nosso País está virando um País de cotas. Tudo tem que 
ter uma cota. Daqui há pouco, fica em segundo plano o serviço prestado, fica em segundo plano o empenho, a dedicação para representar o povo brasileiro. Nós, todos nós sabemos, que nos Estados e Municípios não é vetado a mulher candidata. Não é proibido ser candidata. As cotas para poder serem preenchidas e na maioria dos casos tem que se colocar candidata fantoche. Ora, se nós criarmos cotas obrigatórias, nessa casa, amanhã ou depois teremos deputados federais com 15, 10, 3 mil ou com menos votos. Com todo respeito à bancada feminina, vamos fazer justiça com os brasileiros, vamos acabar com essa história de cotas. Criaram cota para tudo. Absolutamente para tudo tem que ter uma cota, se existem cotas, tem que ser para quem se empenha e trabalha. Não é pela cor, não é pelo sexo, não é pela opção (sic) sexual, mas sim pelo empenho e dedicação. Se vamos reservar cotas, amanhã os homens também vão exigir cotas. Teremos que ter uma cota mínima para que os homens possam estar aqui nessa casa. Logo, logo, teremos os homossexuais com mais uma cota. Então, há cada momento uma cota, outra cota, outra cota, então eu quero aqui fazer um apelo a toda bancada feminina, masculina, independente de sexo, nós parlamentares não estamos aqui, não foi pelo sexo e nem pela opção (sic) sexual. (...) Sou contra. Chega de cota no Brasil. A maior cota que tem que ter é da decência do trabalho e da dedicação. (Deputado João Rodrigues - PSD-SC)

Os discursos, acima descritos, proferidos pelos deputados em plenária, evidenciam a maneira machista, misógina e preconceituosa com a qual a representação feminina na política muitas vezes é tratada. Tal fato é importante também para demonstrar a necessidade e relevância de uma lei que assegure uma participação mínima de mulheres na atividade parlamentar. Através desse mecanismo e com a desconstrução diária dos impedimentos sociais, culturais, econômicos e políticos, será possível garantir uma maior participação feminina na política.

Observamos, ainda, que nos discursos favoráveis há menção da mulher enquanto esposa e mãe, bem como do processo histórico em que foi inserida, além de destaque para o fato de que sendo mais de $50 \%$ (cinquenta) por cento da população não conseguem alcançar $10 \%$ (dez por cento) de representatividade política.

Nos discursos contrários, exarados por dois deputados homens, a história da mulher e seu papel enquanto mãe/ esposa é completamente apagada. De repente, ela se torna um sujeito igual ao homem, com a mesma capacidade de se candidatar e ser eleita. Nenhum dos discursos contrários destacou a desproporcionalidade entre a quantidade de mulheres na população e sua representatividade na política.

As divisões constitutivas da ordem social levam a classificar todas as coisas do mundo e todas as práticas reduzidas a uma oposição entre o feminino e o masculino. Caberia aos homens, situados do lado exterior, do público "realizar todos os atos ao mesmo tempo breves, perigosos e espetaculares, como matar o boi, a lavoura e a colheita, sem falar no homicídio e na guerra" e às mulheres, situadas do lado baixo e úmido "os trabalhos domésticos privados e escondidos ou até mesmo invisíveis e vergonhosos, como o cuidado das crianças e dos animais". 
Sob esse raciocínio, a história da humanidade apresenta a mulher numa situação de inferioridade e opressão. No Brasil, conforme visto, só em 1932, a mulher alcançou o direito ao voto. E mesmo assim, votar não significou ser votada, permanecendo as mulheres longe das decisões políticas e da representação no legislativo e executivo.

Conforme visto, em 1997, a Lei das Eleições implementou um sistema de cotas aos Partidos Políticos para que, obrigatoriamente, apresentassem, 3 (três) candidaturas femininas a cada 7 (sete) candidaturas masculinas. Tal sistemática ao invés de incentivar a participação feminina criou as candidaturas "laranjas", oferecidas tão somente para cumprir a legislação, citadas pela Deputada Carmem Zanotto em seu discurso.

A emenda aglutinativa, aqui analisada, pretendia que as cotas reservadas às mulheres passassem das candidaturas a efetivas vagas no legislativo: Senado, Câmara dos Deputados, Assembleias Legislativas e Câmaras de Vereadores. Sob o percentual mínimo e progressivo de 10, 12 e $15 \%$, durante três legislaturas, após exaustiva negociação da bancada feminina com a liderança dos partidos.

Mesmo assim, o que se viu foi que nem todas as mulheres deputadas se fizeram presentes à sessão. Das cinquenta e uma integrantes, apenas 39 (trinta e nove) participaram da votação e ainda assim, uma delas, como informado, votou contrariamente à emenda proposta.

Durante os debates e pouco antes do início da votação, houve uma longa discussão porque parte da bancada feminina pugnou pela votação de outra emenda aglutinativa $\mathrm{n}^{\circ} 58$, fato que provocou discordância da restante das parlamentares que insistiam que o acordo seria para votar a emenda aglutinativa $\mathrm{n}^{\circ} 57$. A diferença entre uma e outra era o critério de preenchimento das vagas reservadas: na de $\mathrm{n}^{\circ} 57$, a vaga seria preenchida pela proporcionalmente mais votada e na de $\mathrm{n}^{\circ} 58$, seria preenchida pela mulher que obtivesse majoritariamente mais votos.

O racha entre a própria bancada feminina foi uma surpresa para o plenário da Câmara que passou a dedicar grande parte do tempo a decidir qual emenda, então, seria votada, tendo o Presidente, Deputado Eduardo Cunha, mantido a votação da emenda nº57.

O fato é que mesmo com a articulação da bancada feminina, costurando acordos em percentuais mínimos, buscando uma vitória mais simbólica do que propriamente eficaz, o esforço foi em vão. Apesar das poucas vozes expressamente contrárias e da orientação das lideranças partidárias no sentido de se aprovar a matéria ou do parlamentar votar a partir de sua própria consciência, a emenda foi rejeitada.

Aglomeradas no palanque da Câmara dos Deputados, segurando faixas alusivas ao suposto momento histórico, as deputadas brasileiras assistiram atônitas a 101 votos contrários e 53 
abstêmios, que garantiram a hegemonia masculina no Poder Legislativo e confirmaram o mundo andocêntrico que ainda habitamos.

A não aprovação da lei supracitada, enfim, é mais uma comprovação da resistência dos espaços de representação política no Brasil, dominados eminentemente pelo gênero masculino, contra a possibilidade de crescimento da participação feminina nos principais processos decisórios do País.

Dito isso, vale ressaltar, porém que, do ponto de vista sociológico, dificilmente uma lei apenas é capaz de modificar o habitus de uma sociedade. Em outras palavras, se as estruturas sociais, como a educação, o Estado, a religião, a família, a cultura, enfim, todo o ethos de uma sociedade é construído a partir de um viés machista, por exemplo, isso certamente se refletirá e se sobreporá às mais variadas esferas da vida. Podemos dizer que, desse ponto de vista, trata-se daquilo que Marcel Mauss chamou de fato social total:

Nesses fenômenos sociais "totais", como nos propomos chamá-los, exprimem-se, ao mesmo tempo e de uma só vez, toda espécie de instituições: religiosas, jurídicas e morais - estas políticas e familiais ao mesmo tempo; econômicas - supondo formas particulares de produção e de consumo, ou antes, de prestação e de distribuição, sem contar os fenômenos estéticos nos quais desembocam tais fatos e os fenômenos morfológicos que manifestam estas instituições (MAUSS, 1974, p.41).

Através da perspectiva do machismo enquanto um fato social total, isto é, que penetra as múltiplas esferas da vida (familiar, institucional, jurídica, cultural, econômica, religiosa, etc.), não haveria de ser diferente no campo da política, justamente aquele em que talvez a noção de poder se apresente de maneira mais explícita.

Logo, podemos inferir que as mulheres não alcançam as condições exigidas para se obter sucesso nos pleitos políticos devido aos obstáculos que a sociedade dominada pela figura do "masculino" impõe, verdadeiras "paredes sociais", construídas cultural e historicamente.

Após a reprovação da PEC na Câmara dos Deputados, o plenário do Senado, aprovou no dia 25 de agosto de 2015, em primeiro turno, o texto que estabelece cotas para as mulheres nas eleições para as vagas para deputado federal, estadual e vereador. Por se tratar de uma alteração na Constituição, a proposta precisa ser votada em segundo turno no Senado e depois, seguir para análise da Câmara dos Deputados, onde também precisa ser votada em dois turnos para então ser promulgada. A proposta prevê percentual mínimo de representação de cada gênero na Câmara Federal, nas Assembleias Legislativas e nas Câmaras Municipais. O texto estabelece regras para as três legislaturas seguintes àquela a qual a PEC for promulgada. Desse modo, na primeira legislatura a cota englobaria $10 \%$ das vagas, na segunda $12 \%$ e na terceira $16 \%$. 
Convêm acrescentar que não basta apenas a garantia dos percentuais mínimos para ingresso na prática política, a destinação efetiva de parte do fundo partidário para o incentivo e capacitação de mulheres, bem como o investimento em suas campanhas, são pontos que também precisam ser levados em consideração. Permitir que mulheres tenham maior participação nos programas partidários de rádio e televisão se faz necessário para que estas se tornem conhecidas dos eleitores e que, principalmente, estimulem outras mulheres a participarem e entenderem que o espaço da política também a pertence.

\section{AS MUlheres NA POLÍtiCA: "CONDIÇÃo DE GÊNERO” E A ATUAÇão POLÍ́TICA NA ASSEMBLEIA LEGISLATIVA DA PARAÍBA}

A ocupação de mulheres na vida política informal ou institucional tem sido compreendida pelos que se dedicam a essa temática - os intelectuais e o movimento feminista principalmente como um processo de transformação que transcorre entre o silêncio e a voz (PINHEIRO, 2007). Ou seja, há um entendimento de que a não participação feminina nas esferas de poder caracteriza a incompletude da Democracia Representativa. A autora ainda completa afirmando que não há nada que garanta que a maior presença feminina signifique maior defesa dos interesses femininos. Pelo contrário, por essa lógica ocorre a naturalização de um fenômeno que é socialmente construído e mesmo que demonstrem maior participação em áreas de maior vulnerabilidade da sociedade e aos papéis que exercem dentro da esfera privada, não significa, porém, que exista uma espécie de "vocação inata".

Garantir a participação das mulheres nos espaços de poder é, portanto, garantir a completude da Democracia, pois não pode haver Democracia Representativa quando a esmagadora maioria dos cargos eletivos são compostos apenas por um dos gêneros, no caso, o masculino.

No campo do gênero, os homens, como sujeitos pertencentes à estrutura social posta, têm mais liberdade, desfrutam de autonomia, são dominantes nos espaços públicos e de decisão, não necessitando submeter-se a outra categoria de gênero para realizar seus projetos, seus desejos. Já as mulheres, também como sujeitos pertencentes à estrutura social vigente, precisam solicitar autorização à "primeira" categoria. Isso implica afirmar que se a autonomia, o poder de decisão e a maior ocupação de espaços privilegia apenas uma categoria social de sexo, fica patente a hierarquia e a desigualdade. (SCOTT, 1996) 
A categoria de gênero pode ser entendida como elemento essencial para compreender as formas de inserção de mulheres na política e os papeis por elas desempenhados quando se estabelecem nesse meio; nos permite, ainda, entender algumas peculiaridades referentes à relação entre mulheres e a prática política.

Barbosa (2008) compreende a exclusão social e política da mulher na esfera pública pela dimensão relacional onde homens e mulheres não se reconhecem como pares, mas como superiores e inferiores. "A invisibilidade política ou não presença provém da dimensão intrínseca de relações de domínio e subordinação, portanto de relações de gênero." (BARBOSA, 2008, p.01)

Ainda quanto às raízes dessa "desigualdade de gênero", Michelle Rosaldo nos ensina que:

Dada uma divisão empírica entre as esferas de atividade doméstica e pública, diversos fatores interagiriam para aumentar os valores culturais, a força social e a autoridade atribuídas aos homens. Primeiro, parecia que os efeitos psicológicos de ser criado por uma mulher produziriam disposições emocionais muito diferentes em adultos conforme o sexo; por causa da divergente natureza dos laços préedipianos com suas mães, meninas cresceriam para ser 'mães', nutrizes enquanto garotos adquiriam uma identidade que denigre e rejeita os papéis das mulheres. (ROSALDO, 1995, p. 13)

No que se refere a essas "distinções de gênero", Rosaldo acrescenta que: "gênero em todos os grupos humanos deve então ser entendido em termos políticos e sociais com referência não a limitações biológicas, mas sim às formas locais e especificas de relações sociais e particularmente de desigualdade social”. (ROSALDO, 1995, p. 16)

Outro fato que merece destaque quando pensamos sobre as condições de disputa e de inserção das mulheres em espaços de poder diz respeito as suas trajetórias pessoais e públicas, em outras palavras, como estas construíram a sua imagem privada e pública e a relação entre estas e as vivências e alianças políticas construídas por meio de atuação sindical e/ou através de "nomes de família", de prepostos ou de um capital político inexistente, já que a experiência apresentada pode ter se dado exclusivamente no campo do espaço doméstico, ou seja, privado:

Como grupo em posição de desigualdade estrutural, historicamente subordinado, as mulheres não possuem as mesmas condições de acesso às arenas políticas e aos canais de poder que os homens, devido aos limites impostos pelo seu papel social (...) Além disso, diferentemente do homem, os ciclos de vida da mulher segmentam a sua vida, em particular, com o advento da maternidade. (RABAY \& CARVALHO, 2010, p. 33)

Ás vezes, diante de um contexto de dificuldades e obstáculos, várias mulheres se inserem no meio político vinculadas a "nomes de família" (marido, filhos, tios, irmãos) e a grupos oligárquicos 
liderados comumente por homens. A inserção política via esses "nomes" trata-se assim, como nos colocam Rabay e Carvalho (2010), de um recurso que "resolve todos os impedimentos estruturais, institucionais e individuais, uma vez que libera, convida, inicia e apoia a mulher na vida pública e na política partidária”. (RABAY \& CARVALHO, 2010, p. 36). Este nos parece ser ainda, a via mais fácil de acesso aos espaços de poder político. Uma trajetória política baseada na experiência e na militância é algo que nosso sistema político consegue garantir a poucas representantes políticas do sexo feminino.

Assim, as carreiras políticas das mulheres se tornam reconhecidas e se legitimam a partir da exaltação de certos "atributos e valores femininos" como uma exigência de uma sociedade pautada na reprodução e persistência do papel tradicional da mulher: mãe, esposa, dona de casa, cuidadora, abnegada, frágil, generosa. Dessa forma, essas mulheres se lançam nos espaços de poder a partir da constituição de imagens públicas de mulheres competentes, independentes e, sobretudo, de detentoras de um diferencial no que se refere ao padrão de gestão masculino. Dessa forma, elaboram Miguel e Biroli (2011): as mulheres utilizam-se do chamado "pensamento maternal" ou "política do desvelo".

Devido à socialização diferenciada por que passam as mulheres engendraria uma sensibilidade e um julgamento moral específicos, opostos aos masculinos dominantes. (MIGUEL \& BIROLI, 2011, p. 78).

O poder e a prática política transitam por diversos significados, no entanto, estes quando se referem às mulheres parecem estar intrinsecamente associados à sensibilidade, ao cuidado e, sobretudo, à maternidade. Tais características se explicitariam seja pela natureza (fator biológico e a crença de que a mulher nasce mais apta para a doação e preocupação com o outro), seja pela educação (a mulher é historicamente socializada e literalmente ensinada às práticas do zelo e do cuidar).

Diante esse contexto de representação feminina, tomamos como caso a presença de mulheres na Assembléia Legislativa da Paraíba (ALPB). Os números das três últimas eleições, ratificam a ainda moderada participação de mulheres na política.

A Assembleia Legislativa da Paraíba, que completou 180 anos de história em abril de 2015, mostra como a participação feminina neste âmbito de poder, trata-se de um fato recente na constituição do poder legislativo paraibano. A Casa que é datada de 05 de abril de 1835, só teve em 1982, 147 anos após a sua instalação, a primeira representante do sexo feminino, a deputada Vani Leite Braga de Figueiredo, irmã de Wilson Braga, eleito governador do Estado no mesmo ano. Passados 32 anos após a eleição da primeira deputada, apenas 24 mulheres ocuparam as cadeiras da 
ALPB. Este número foi alcançado na última eleição, em 2014, com os mandatos de Camila Toscano (PSDB) e Estelizabel Bezerra (PSB). Na atual legislatura também encontra-se a deputada reeleita, Daniella Ribeiro (PP).

Em declaração dada ao site oficial da Assembleia Legislativa, a deputada Estelizabel Bezerra (PSB) atribuiu a baixa presença de mulheres na política à existência de uma democracia ainda em formação:

A subrepresentação das mulheres na Assembleia Legislativa e nos espaços de representação política é sintoma de uma democracia ainda não plena. Pouco mais da metade da população não pode estar ausente ou sub-representada em espaço tão determinante para a vida em sociedade. (http://www.al.pb.gov.br/17563/assembleia-180-anos-a-historia-da-participacaofeminina-no-legislativo-paraibano.html. 02 de abril de 2015. Acesso em 14 de setembro de 2015)

A deputada, Camila Toscana (PSDB) acredita ainda ser preciso mais mulheres ocuparem os espaços de poder público:

Nos últimos anos avançamos muito, mas ainda há muito para avançar. Temos que ocupar mais espaços, pois esta é uma forma de empoderamento para as mulheres. É fundamental a participação da mulher na política para mostrar que somos aptas a ocupar qualquer cargo e que não existe distinção entre homens e mulheres. (http://www.al.pb.gov.br/17563/assembleia-180-anos-a-historia-da-participacaofeminina-no-legislativo-paraibano.html. 02 de abril de 2015. Acesso em 14 de setembro de 2015)

No período de 32 anos, que vai do ano de 1982 a 2014, a Assembleia Legislativa da Paraíba teve 24 mulheres ocupando suas cadeiras, sendo elas titulares ou suplentes: Vani Braga, Lúcia Braga, Terezinha Pessoa, Geralda Medeiros, Francisca Motta, Estefânia Maroja, Zarinha Leite, Socorro Marques, Lucinha Monteiro, Edina Wanderley, Giannina Farias, Eurídice Moreira (Dona Dida), Iraê Lucena, Léa Toscano, Daniela Ribeiro, Eva Gouveia, Gilma Germano, Flora Diniz, Nadja Palitot, Olenka Maranhão, Marta Ramalho, Nárriman Xavier, Estela Bezerra e Camila Toscano. (http://www.al.pb.gov.br/17563/assembleia-180-anos-a-historia-da-participacao-femininano-legislativo-paraibano.html. 02 de abril de 2015. Acesso em 14 de setembro de 2015).

Para ilustrarmos ainda mais a situação de sub-representação da mulher na Assembléia Legislativa da Paraíba passamos a descrever abaixo, em forma de tabelas, os resultados das três últimas eleições, 2006, 2010 e 2014.

\section{Eleições 2006}




\begin{tabular}{|c|c|c|}
\hline Total de candidatos & Homens & Mulheres \\
\hline 250 & 227 & 23 \\
\hline Total de eleitos & Homens & Mulheres \\
\hline 31 & 27 & 04 \\
\hline
\end{tabular}

Eleições 2010

\begin{tabular}{|c|c|c|}
\hline Total de candidatos & Homens & Mulheres \\
\hline 256 & 216 & 40 \\
\hline Total de eleitos & Homens & Mulheres \\
\hline 32 & 26 & 06 \\
\hline
\end{tabular}

Eleições 2014

\begin{tabular}{|c|c|c|}
\hline Total de candidatos & Homens & Mulheres \\
\hline 306 & 217 & 89 \\
\hline Total de eleitos & Homens & Mulheres \\
\hline 36 & 33 & 03 \\
\hline
\end{tabular}

A partir da análise dos números das três últimas eleições, referentes as candidaturas e eleição de deputadas estaduais, observa-se a ainda pequena participação feminina nessa esfera de poder. Mesmo com todas as conquistas alcançadas pelas mulheres ao longo de décadas, ainda se faz necessário problematizar e apontar as diversas dificuldades que estas continuam a enfrentar. As mulheres ainda recebem salários inferiores aos dos homens, para exercerem as mesmas atividades e por vezes não são devidamente reconhecidas e/ou impedidas de ocuparem determinados espaços, 
pelo simples fato de serem mulheres; são diariamente assediadas e julgadas por sua liberdade sexual ou pela roupa que vestem, são agredidas e mortas diariamente, na maioria das vezes, por seus próprios companheiros, pelo fato destes ainda a enxergarem como suas propriedades. Nesse sentido, debater essas questões e reivindicar uma maior participação de mulheres nas tomadas de decisão e poder, é essencial.

Sob esses aspectos, as tabelas acima descritas, apontam, ainda, para um fato extremamente importante: em nenhuma das três últimas legislaturas, o percentual mínimo de $30 \%$ das candidaturas destinadas às mulheres foi cumprido, por isso questionamos alhures, a efetividade da Lei de Cotas. Como apontam os dados, no ano de 2006, para que a cota mínima fosse cumprida, teriam sido necessárias a candidatura de 75 mulheres, um número bastante inferior as 23 candidaturas femininas daquele ano. Na eleição seguinte, no ano de 2010, houve uma maior adesão de candidaturas de mulheres, no entanto, das 76 candidaturas necessárias, apenas, 40 foram registradas. Na última eleição, no ano de 2014, o número mínimo exigido aproximou-se bastante das 89 candidaturas, ainda assim, para atingir o percentual dos $30 \%$ teriam sido necessárias $91,8 \%$ de candidaturas femininas.

Com base nesses dados nos é possível fazer algumas considerações. A não exigência do efetivo cumprimento da Lei de Cotas, a não fiscalização por parte do Tribunal Superior Eleitoral, por exemplo, e a não punição dos Partidos Políticos pelo descumprimento da lei, são fatores que corroboram para a não eficácia da Lei de Cotas. Assim como o tratamento dado pelos partidos as candidaturas femininas, que parecem trata-las como "elementos de segunda classe" no meio eleitoral, já que não disponibilizam os mesmos recursos financeiros e estruturais que possam efetivamente preparar essas mulheres candidatas com reais possibilidades de disputa e êxito.

Como já exposto, a Lei de Cotas é concebida como uma política compensatória que busca equiparar os direitos sociais e civis de homens e mulheres. A histórica e cultural subordinação a qual as mulheres foram e ainda são submetidas, são expressas nos números referentes à sua inexpressiva participação na política. Os dados das três últimas eleições para deputado estadual na Paraíba, como vimos, é reflexo de uma sociedade que ainda determina lugares sociais diferentes para homens e para mulheres. Assim, entendemos a cultura como elemento fundamental para a análise e compreensão da prática política brasileira. Entender os papeis sociais construídos e destinados a cada um dos sexos ao longo da história, nos permite compreender também as estruturas sociais que permeiam e sustentam a prática política que é masculina e sexista. Sob esse aspecto Rabay e Carvalho (2010) formulam que: 
Há muito tempo, o seu ambiente e as suas práticas, foram e (são) frequentados e exercitados exclusivamente por homens, a ponto de adquirirem as marcas peculiares desse grupo. Essa afirmação é válida para uma sociedade que separa homens e mulheres, institui uma divisão social/sexual do trabalho e constrói duas culturas de gênero (masculina versus feminina). (RABAY \& CARVALHO, 2010, p. 38)

Fatores econômicos e a própria constituição do sistema político brasileiro, determinam a destinação das vagas nos espaços da política, contudo, a cultura e suas formas de representação, também tem determinação fundamental nessa estruturação.

Outro fato que deve ser discutido, quando analisados os números das eleições na Paraíba, é a presença constante dos "nomes de família" na constituição das candidaturas e carreiras políticas femininas. Rabay e Carvalho (2010), afirmam que, sobretudo no Nordeste, há uma instrumentalização das "mulheres da família" por parte das oligarquias, visando à perpetuação no poder. Assim como citado, a maioria das 24 mulheres eleitas nos últimos 32 anos para a ALPB é oriunda de grupos familiares representados por figuras masculinas de grande prestígio e poder no cenário político. Das três representantes femininas na atual legislatura, duas tem sua constituição enquanto mulher pública e política, na origem familiar. Camila Toscano (PSDB) é filha do exdeputado estadual e ex-prefeito de Guarabira (PB), Zenóbio Toscano e de Léa Toscano, também exdeputada estadual. Daniella Ribeiro (PP) é filha do ex-prefeito de Campina Grande (PB), Enivaldo Ribeiro e irmã do atual deputado federal pela Paraíba e ex Ministro das Cidades, Aguinaldo Ribeiro. As duas deputadas tem como parentes diretos, nomes masculinos expressivos na política partidária paraibana e nacional.

O "apadrinhamento político" e a sucessão familiar na política são práticas comuns à estrutura política local e nacional. No entanto, quando estes englobam mulheres políticas, parecenos serem negativados e desprestigiados, colocando tais candidaturas ou legislaturas, possíveis apenas pela instituição dos "nomes de família". Mais que aos homens, que por vezes vivenciam o mesmo processo, há uma espécie de desqualificação e negação de competência para a ocupação daquele espaço. Grupos familiares parecem ser uma das vias de acesso mais fáceis para a inserção de mulheres na política. Desse modo, assim como destacam Rabay e Carvalho (2010), este não deve ser encarado como um meio ilegítimo ou de pouco prestígio, mas como um meio facilitador que desconstrói alguns dos elementos estruturais e culturais que dificultam a instituição de mulheres no espaço da política. A representação feminina construída a partir dos "nomes de família" torna-se ineficaz, se assim como acontece nas famílias, estas mulheres tornarem-se subordinadas às relações 
patriarcais de poder e dominação e pautarem seus mandatos unicamente na manutenção do poder oligárquico e de base familiar.

\section{UM POUCO DA ATUAÇÃO PARLAMENTAR DA 'BANCAdA FEMININA' NA ASSEMBLEIA LEGILATIVA DA PARAÍBA}

Como já mencionado alhures, atualmente a bancada feminina na Assembléia Legislativa do Estado da Paraíba é composta por três parlamentares: Camila Araújo Toscano de Moraes (PSDB), Daniella Veloso Borges Ribeiro (PP) e Estelizabel Bezerra de Souza (PSB). Com o intento de analisarmos um pouco a atuação parlamentar das deputadas eleitas no pleito de 2014, fizemos uma seleção das principais reportagens divulgadas pelos portais online e blogs locais referentes ao desempenho e ações das deputadas na Assembléia. Também foram consultados perfis nas redes sociais, alimentados pelas próprias deputadas ou por suas equipes de assessoria. As informações coletadas datam do mês de janeiro de 2015, quando as mesmas foram empossadas e nomeadas, até fim de julho do mesmo ano.

Antes de dar início à análise propriamente dita dos dados, necessário se faz apresentar um breve histórico sobre o perfil pessoal e político de cada uma das deputadas citadas:

Camila Araújo Toscano de Moraes nasceu em João Pessoa, na Paraíba, no dia 15 de outubro de 1980, é formada em Direito pelo Unipê (Centro Universitário de João Pessoa). Foi eleita deputada estadual pelo Partido Social da Democracia Brasileira (PSDB) com 32.682 votos (1,63\%). É filha do ex-deputado estadual e ex-prefeito de Guarabira (PB), Zenóbio Toscano e da também exdeputada estadual e ex-prefeita de Guarabira, Léa Toscano. A deputada cumpre seu primeiro mandato. Este é seu primeiro contato com a vida pública. Atualmente é membro do Conselho de Ética e Decoro Parlamentar da Assembleia, da Comissão de Constituição e Justiça e presidente da Comissão dos Direitos da Mulher.

A outra deputada, Daniella Veloso Borges Ribeiro, nasceu em Campina Grande, na Paraíba, em 26 de março de 1972. É formada em Pedagogia pela Universidade Federal da Paraíba (UFPB). É filha do ex-deputado federal pela Paraíba e ex-prefeito de Campina Grande, Enivaldo Ribeiro e irmã do atual deputado federal e ex-Ministro das Cidades, Aguinaldo Ribeiro. Iniciou sua trajetória política candidatando-se a vice-prefeita de Campina Grande na chapa de Rômulo Gouveia em 2004, não obtendo êxito. Em 2008 foi eleita vereadora de Campina Grande com 6.838 votos. Já no ano de 2010 elegeu-se para seu primeiro mandato como deputada estadual pela Paraíba, com 29.863 votos. 
No ano de 2012 afastou-se da Assembleia para disputar o cargo de prefeita em Campina Grande, sem êxito. Foi reeleita e exerce atualmente mandato de deputada estadual com 46.938 votos $(2,34 \%)$ pelo Partido Progressista (PP).

Estelizabel Bezerra de Souza nasceu em João Pessoa, na Paraíba, em 18 de março de 1967. É formada em Jornalismo pela Universidade Federal da Paraíba (UFPB). Foi coordenadora de Políticas para as Mulheres na prefeitura de João Pessoa, onde ainda ocupou as pastas de Transparência, Orçamento Democrático e Planejamento. Disputou o cargo de prefeita na cidade de João Pessoa em 2012, sem obter êxito. Atuou ainda como secretária estadual de comunicação e Chefe de Gabinete no primeiro mandato do governador Ricardo Coutinho. Foi eleita para seu primeiro mandato como deputada estadual com 34.929 votos $(1,74 \%)$ pelo Partido Socialista Brasileiro (PSB). Atualmente é membro do Conselho de Ética e Decoro Parlamentar, preside a Comissão de Constituição e Justiça, é membro da Comissão de Direitos Humanos e Minorias, da Comissão de Educação, Cultura e Desportos, além de ser vice-presidente da Comissão de Direitos da Mulher.

Ao nos depararmos com a participação das parlamentares nesses nichos específicos, torna-se notória a observação feita por Miguel e Biroli (2011), para quem, as mulheres devido a sua socialização diferenciada e subjugação histórica à esfera do lar, do cuidado maternal e da abnegação em nome do outro, ao entrarem no meio político acabam sendo conduzidas à manutenção de algumas dessas práticas culturalmente apreendidas. Desse modo, é comum encontrarmos mulheres políticas advogando na área das causas de cunho social, aquelas que têm como foco a assistência e a proteção do outro, este geralmente fragilizado e impossibilitado de atender às suas necessidades. É necessário notarmos que este tipo de "cuidado e proteção" remete aos papeis da mãe e da dona de casa, sempre dispostas a se doar ao outro. Nesse sentido, os autores afirmam que:

Há indícios de que as mulheres se ocupam com mais frequência de temas ligados à área social do que aquelas vinculadas diretamente ao controle do Estado e de seus recursos e à distribuição dos postos de exercício de poder. (MIGUEL \& BIROLI, 2011, p.80).

O questionamento feito pelos autores é o de se essa "propensão" à área social seria uma opção, ou justamente uma falta de opção: as mulheres encontrariam nesse nicho o único meio e temas disponíveis para sua atuação no meio político.

Outro ponto a ser observado em relação à necessidade da participação de mulheres na política seria o de que somente elas seriam capazes de dialogar e propor as demandas exigidas pela parcela feminina da sociedade. Sob esse aspecto, as mulheres teriam interesses especiais e legítimos 
ligados ao gênero. No entanto, Miguel e Biroli (2006) afirmam haver nessa crença um essencialismo subjacente:

Parece que as mulheres, apenas por serem mulheres, terão sempre interesses idênticos. Contra isso, há o fato de que os indivíduos ocupam, ao mesmo tempo, diferentes 'posições de sujeito', cujas pressões são variadas e por vezes, contraditórias. (MIGUEL \& BIROLI, 2006, p. 26).

Mulheres candidatas ou já inseridas na prática política (na forma de um mandato) muitas vezes não são necessariamente comprometidas com a questão feminina ou de uma pauta feminista. Diante desses argumentos, passamos a expor algumas das propostas e ações empreendidas por cada uma de nossas representantes femininas na Assembleia Legislativa da Paraíba.

Sobre a deputada Daniella Ribeiro merece destaque a apresentação de um requerimento junto à Assembleia que propõe a realização de campanhas para beneficiar os portadores de necessidades especiais no mercado de trabalho e nas atividades do dia-a-dia da sociedade. A líder do Partido Progressista na Assembleia Legislativa ainda propôs ações em torno da união da sociedade na prevenção e combate às drogas com o objetivo de contribuir para que determinadas faixas da população não sejam vítimas "desse mal que penaliza as famílias". Ela convocou a união de forças "para que todos lutem contra essa mazela que castiga a população. Somos contra a droga e em favor da vida", afirmou a Deputada, na defesa de seu requerimento.

Um Projeto de Lei apresentado ainda pela deputada, o de número 350, que mereceu destaque dos mass media foi o que objetivou instituir o Programa de Acolhida dos Moradores de Rua. O intento é desenvolver campanhas de acolhida aos moradores que vivem nas ruas das cidades da Paraíba e como ação concreta a sua proposta é que sejam construídos centros de abrigos que disponibilizem banho e alimentação, guarda-volumes e segurança a essa população que mora nas ruas. Assim ela se expressou:

Nossa proposta tem por princípio atender, dentro das possibilidades, as necessidades das pessoas em situação de rua, visando resgatar os princípios básicos da dignidade humana, que só são possíveis se a sociedade se unir e chamar para si a responsabilidade da ação. Muitas dessas pessoas sofrem com os problemas das drogas e do alcoolismo. (www.daniellaribeiro.com.br. Acesso em 14/11/ 2015).

Outra Lei de autoria da parlamentar previu a proibição de comercialização, produção e distribuição de armas de brinquedo, a deputada descreveu a importância da lei como um meio capaz de "incentivar, desde cedo, a cultura da paz e da não-violência no Estado da Paraíba; 
O objetivo desta lei é promover a educação das crianças, trabalhando para que desfrutem de uma vida sem violência e ensinem aos adultos que o melhor caminho é o caminho da paz; e para serem, eles mesmos, adultos melhores. A lei veio para complementar esse trabalho contínuo de preservação da inocência das nossas crianças e, consequentemente, adultos mais equilibrados, num verdadeiro círculo virtuoso de paz. (www.caldeiraodochico.com.br. Acesso em 14/11/ 2015).

Algumas das matérias propostas por Daniella Ribeiro remetem ao cuidado inato ao sujeito feminino. A preocupação com a desestruturação familiar, com o acolhimento dos desabrigados, com os marginalizados pela sociedade e com as crianças, grupo vulnerável, reforçam a ideia da "política do desvelo" (MIGUEL, 2001) que reforça os papeis de gênero desenvolvidos pelas mulheres na sociedade.

Como ação prioritária para o ano de 2015, a partir do mês de março de 2015 em comemoração ao dia Internacional da Mulher, 08 de março, a deputada Daniella Ribeiro, em um outro de seus pronunciamentos, afirmou que estava dando início a uma série de ações com vistas a combater a violência contra a mulher, sobretudo, a violência psicológica, assim formulou a parlamentar:

\begin{abstract}
Xingamentos, ameaças verbais e humilhações, sejam elas públicas ou não, são apenas algumas das diversas formas de se coagir uma mulher, muitas vezes colocando-a em constante estado de pânico ou, até mesmo, em surto psicológico. Nosso dever é garantir o mínimo de ajuda para que essas mulheres possam sair dessa prisão imposta em casa. (www.paraibaurgente.com.br. Acesso em 20/08/ 2015).
\end{abstract}

Em um de seus perfis nas redes sociais, a bandeira de combate à violência psicológica contra as mulheres foi a mais discutida e exposta pela deputada. $\mathrm{O}$ incentivo à denúncia e o diálogo com toda a sociedade sobre o problema social é recorrentemente salientado pela parlamentar.

Em seu primeiro mandato na atividade política como Deputada Estadual, Camila Toscano apresentou Projeto de Lei que dispõe sobre a obrigatoriedade de estágios em escolas públicas para estudantes de universidades públicas estaduais com licenciatura plena. A deputada apresentou ainda, projeto de lei que prevê a instalação de bibliotecas nos hospitais públicos da Paraíba, assim explicou a parlamentar:

As pessoas passam muito tempo internadas em hospitais, inclusive crianças. Então, nada mais adequado que criar estes espaços e utilizá-los de forma útil. Nossa intenção é ajudar a incentivar a leitura e proporcionar entretenimento aos pacientes e familiares que precisam passar longos períodos hospitalizados. (http://www.maispb.com.br/133665/projeto-garante-bibliotecas-em-hospitais.html, 27/10/2015. Acesso em 15/10/2015). 
E acrescentou:

Os hospitais inseridos nessa Lei deverão, dentro de sua dotação orçamentária, promover campanhas locais com o incentivo de arrecadar doações de seus próprios pacientes e familiares. (http://www.maispb.com.br/133665/projeto-garantebibliotecas-em-hospitais.html, 27/10/2015. Acesso em 15/10/2015).

Suas mais destacadas proposituras e discussões na Assembleia tem se direcionado aos direitos da mulher, já que a mesma foi eleita presidente da Comissão da Mulher em abril de 2015. A deputada afirma ser dever da casa acompanhar os assuntos ligados às mulheres em todas as áreas, principalmente, no combate à violência. Ela defende também, maior capacitação da mulher e inclusão no mercado de trabalho e geração de emprego e renda. "Este aspecto é fundamental para a mulher se libertar da violência".

A mortalidade materna no Estado foi um dos assuntos discutidos em meados do mês de julho de 2015, em numa audiência pública, como proposta da deputada Camila Toscano: "Nós, enquanto poder público, não estamos cuidando bem de nossas gestantes e elas estão morrendo, seja por falta de um pré-natal bem feito e adequado...". Ainda no fim do mês de julho do referido ano, após o recesso parlamentar, a deputada convocou audiência pública para discutir a violência contra as mulheres no Estado:

O assunto é sério e merece a atenção dessa Casa. A Paraíba vem colecionando casos de horror. A barbárie de Queimadas, o crime com as duas mulheres e um bebê do bairro dos Bancários e fatos emblemáticos, ainda sem solução da polícia, como o assassinato na menina Rebeca, são alguns dos exemplos de crimes graves e que deixam assustadas todas nós, mulheres, que vivemos nesse Estado. (www.facebook.com/camila45123, acesso em 04/08/2015).

Ainda no mesmo mês a parlamentar apresentou Projeto de Lei que prevê a reserva de 5\% das vagas para as mulheres operárias na construção civil em obras a serem executadas pelo Governo do Estado:

Nosso objetivo é que as mulheres sejam inseridas na construção civil, que ainda é um ambiente predominantemente masculino. O projeto tem a intenção de fazer essa reserva nas obras públicas para garantir maior participação da mulher. Já temos muitas delas se qualificando e trabalhando na área, mas queremos que sejam inseridas nas obras do Estado. (http://www.plugadosnanoticia.com/2015/07/projeto-de-camila-toscano-prevereserva.html. Acesso em 04/08/2015). 
Com base nas informações apresentadas, pode-se atrelar as práticas políticas da deputada Camila Toscano à sua "condição de gênero". O fato de ser mulher parece garantir à mesma maior credibilidade e competência para tratar dos assuntos referentes à cidadania feminina. Sua "condição de gênero" permite maior aptidão para conduzir às discussões de interesse feminino, a maternidade, a inserção e ampliação de oportunidades no mercado de trabalho e o combate à violência sofrida por diversas mulheres.

Após ser eleita, Estelizabel Bezerra, também conhecida no Estado e em época de campanha eleitoral como Estela Bezerra, afirmou ter alcançado a vaga na Assembleia Legislativa para contribuir na política com tudo aquilo que sempre defendeu, todos os aspectos concernentes ao público heterogêneo formado pelos "LGBT", deficientes, mulheres, negros e jovens. Desse modo, no mês de maio, a deputada criou a Frente Parlamentar de Apoio à Cidadania LGBT e Enfrentamento à Homofobia. A esse respeito, a deputada afirmou haver, ainda no país o incômodo muito grande das pessoas em relação à orientação sexual umas das outras:

Esse sentimento se transforma em ação de violência, supressão de direitos e até de cerceamento da própria vida, e esse tipo de crime, que é o crime de ódio por orientação sexual, é sequer tipificado no nosso país. (www.portaldolitoralpb.com.br. Acesso em 29/04/2015).

E acrescentou, desafiadoramente aos seus pares do parlamento paraibano:

Vamos marcar a postura política dessa Casa que é de cidadania e de respeito às pessoas independente da cor, do credo ou orientações sexuais. A particularidade que nos enriquece na diversidade não pode ser usada como condenação e como diminuição da nossa humanidade. (www.portaldolitoralpb.com.br. Acesso em 29/04/2015).

É também sua propositura a criação da Frente Parlamentar Ambientalista, que pretende discutir os níveis de desenvolvimento sustentável (sugestão da ONU - Organização das Nações Unidas, ao invés da mediação dos níveis de desenvolvimento social).

$\mathrm{Na}$ data de celebração dos 82 anos de conquista do voto feminino do Brasil ( 24 de fevereiro de 2015), Estelizabel Bezerra ressaltou que mais da metade da população brasileira é formada por mulheres, sendo assim, imprescindível a presença feminina na construção da democracia. A deputada lembrou ainda o acúmulo de funções que as mulheres enfrentam diariamente: "Precisamos aprimorar esse item, é necessário que homens e mulheres tenham atribuições iguais nas esferas públicas e privadas, com divisões de tarefas de forma mais justa". (www.politicahora1.blogspot.com.br. Acesso em 24/02/2015). 
Para ela, homens e mulheres têm condições iguais de contribuir para a construção da democracia. "Apesar de 82 anos de uma conquista tão importante, temos apenas três deputadas estaduais, então ainda precisamos avançar muito no espaço político". (www.politicahora1.blogspot.com.br. Acesso em 24/02/2015).

Em audiência pública realizada na Assembleia com o apoio da parlamentar Estelizabel Bezerra, no dia 24 de julho de 2015, debateu-se a questão da mulher negra na Paraíba. A audiência ocorreu em alusão ao Dia da Mulher Afro-Latina-Americana e Caribenha. Em seu pronunciamento, esclareceu a parlamentar:

No Brasil, mais de 49 milhões de pessoas da nossa população é composta de mulheres negras, mas que não tem o reconhecimento da sua contribuição na construção da cultura da nossa região. A dificuldade de acesso às políticas públicas e a falta de garantia de direitos é a verdadeira motivação da necessidade de se discutir e de modificar essa quantidade de coisas (...) É um segmento significativo que requer políticas públicas. Quando observamos indicadores sociais são essas mulheres quem menos estão na escola, que recebem os piores salários e são acometidas de algumas patologias específicas das condições de vida e de opressão desse segmento. (www.geledes.org.br. Acesso em 24/07/2015).

Em sessão de autoria da deputada Estelizabel Bezerra, em alusão ao Dia Internacional da Mulher, 08 de março, foi discutido o papel das políticas públicas na vida das mulheres. Segundo a deputada, os objetivos da sessão foi reunir quem vem historicamente lutando para corrigir esta desigualdade e ao mesmo tempo as forças institucionais que de certa forma tem a responsabilidade de implementar políticas públicas. Assim denunciou a parlamentar em seu discurso:

O salário da mulher ainda é 30\% abaixo do que recebe um homem. Somos mais da metade da população, mas não ocupamos os cargos de ocupação política e econômica nesta mesma proporção. (www.facebook.com/EstelaBezerraOficial. Acesso em 08/03/2015)

Assim como as proposituras, sessões e projetos de lei criados por Camila Toscano, as ações de Estelizabel Bezerra voltam-se para a defesa de políticas de inclusão e reconhecimento da desigualdade histórica à qual as mulheres foram subjugadas. A discussão em torno de uma maior representatividade feminina na política corrobora com as concepções de que as mulheres são as mais indicadas para defenderem os seus próprios interesses como também os interesses de todos. A incidência maior de pautas do gênero referentes às duas deputadas pode ser explicada também pelo fato de uma ser presidente e a outra vice da Comissão dos Direitos da Mulher. 
Durante a pesquisa de dados aqui expostos, uma reportagem veiculada pelo portal ClipPB, dedicou-se à atuação e número de proposituras, especificamente construídas pelas representantes femininas na Assembleia Legislativa:

Nesta, 81 matérias entre Projetos de Lei, Resoluções e Requerimentos foram apontados como de autoria das três deputadas. Separadamente, Daniella Ribeiro, em seu segundo mandato, apresentou, até o momento: 8 Projetos de Lei, 2 Projetos de Resolução, 20 Requerimentos e 3 pedidos de sessão especial, totalizando 33 matérias. Estelizabel Bezerra apresentou 2 Projetos de Lei Ordinária, 1 Projeto de Resolução, 2 Requerimentos e 2 pedidos de sessão especial, totalizando 17 matérias. Camila Toscano apresentou 2 Pedidos de Informação, 9 Projetos de Lei Ordinária, 19 Requerimentos e 1 pedido de sessão especial, totalizando 31 matérias. (http://www.clickpb.com.br/. Acesso em 08/11/2015)

Os dados acima descritos são do Portal Transparência da Assembléia Legislativa da Paraíba (www.al.pb.gov.br). A referida reportagem pode ser remetida a uma espécie de fiscalização da competência específica de mulheres políticas. A necessidade de afirmação constante de eficiência, aptidão e mérito por parte das mulheres que adentram o cenário político é observado empiricamente em diversas situações da prática política.

\section{CONSIDERAÇÕES FINAIS}

Entender a definição de papeis sociais distintos e determinados para homens e para mulheres nos permite compreender a relação entre condição de gênero e a esfera política. A delegação do espaço privado, da casa, dos filhos e do marido para as mulheres e do espaço público, o mercado de trabalho e todas as atividades sociais fora do ambiente da casa, para os homens, significou e, em certo sentido, continua a significar, o impedimento de acesso livre, igualitário e legítimo as mulheres no espaço da política. A organização delas em torno da desnaturalização desses papeis e espaços sociais e da imposição como grupo de cidadãs dignas dos mesmos direitos que os homens, implicam nos primeiros elementos de constituição de suas liberdades e autonomia, em especifico na política.

A inserção da mulher no mundo da política é um desafio, sobretudo em países como o Brasil, onde o sistema patriarcal define em grande medida os papeis sociais que homens e mulheres devem assumir seja culturalmente, socialmente ou politicamente. A divisão sexual do trabalho se mostra como um dos grandes empecilhos que fazem com que muitas mulheres sejam privadas de vivenciar o mundo político. Boa parte das pessoas do sexo feminino convive com o fato de ter que 
lidar com a dupla (até tripla) jornada de trabalho, um fator de peso que acaba por desestimular centenas de mulheres na buscar por uma carreira política.

Apesar de o Brasil contar com uma política de cotas de gênero nos partidos, o que pudemos observar é o baixo percentual de mulheres ocupando cargos eletivos em todas as esferas do poder público. Segundo o TSE apenas $10 \%$ das pessoas que ocupam cargos eletivos no Congresso Nacional, por exemplo, são do sexo feminino. É certo que esse número vem aumentando; segundo os dados do TSE o número de mulheres em disputa por algum cargo nas Eleições Gerais do ano de 2014 foi 46,5\% maior do que no último pleito, em 2010, no entanto poucas foram as que conseguiram eleger-se, de tal sorte que podemos facilmente aferir a situação de sub-representação da mulher na política seja na esfera legislativa, seja na executiva, bastando consultar os dados do Supremo Tribunal Eleitoral.

Além dos poucos avanços na efetiva participação feminina nos espaços de poder, a política brasileira sofreu algumas mudanças importantes que podem nos indicar uma transformação, ainda que tímida, nas relações dos brasileiros com sua própria cultura política, entre elas destacam-se a utilização da internet como ferramenta para ampliação das campanhas eleitorais e como espaço para o estreitamento dos laços sociais entre candidatos e eleitores através do mundo virtual. Esses dois fatores, a principio, podem parecer elementos não pertencentes ao mesmo conjunto. Porém o estudo da utilização da internet como ferramenta política pode nos auxiliar na analise da construção e desconstrução das imagens públicas das mulheres que decidem enfrentar o sistema patriarcal e vivenciar de diversas formas a vida política.

A partir do levantamento de dados e de alguns apontamentos aqui expostos, é possível afirmar que a atuação das parlamentares, Camila Toscano, Daniella Ribeiro e Estelizabel Bezerra está interligada à "condição de gênero" das mesmas. As atividades em plenária e os discursos das deputadas denotam a defesa de pautas específicas para as mulheres, tais como: combate à violência, políticas de inclusão, maiores oportunidades de emprego e melhores salários, maior e melhor assistência à mulher em condição de maternidade e maior participação de mulheres no meio político.

Necessário se faz destacar que temas de reivindicação de uma pauta feminista não configuram os debates propostos por nenhuma das deputadas: a descriminalização do aborto, direitos reprodutivos e ao corpo, por exemplo, ainda não foram, até o momento, debatidos e/ou incorporados aos discursos das parlamentares. 
Tal observação leva-nos a crer quão tímida é ainda a participação e os espaços de poder conquistados pelas referidas parlamentares num ambiente ainda marcadamente masculino e muitas vezes, misógino.

A deputada Estizabel Bezerra, como vimos ao longo do artigo, é quem apresenta uma pauta mais progressista, ao defender o respeito a diversidade e a multiplicidade culturais, no entanto, está longe de defender pautas reivindicadas pelo movimento feminista; compreendemos a grande dificuldade tanto para homens quanto para mulheres em "levantarem certas bandeiras feministas" tais como: a liberalização do aborto, direitos reprodutivos e o casamento gay. Numa sociedade marcada por valores entrecortados por uma moral burguesa e religiosa, expor esse tipo de defesas é ganhar a simpatia de uma pequena parcela da sociedade e perder de uma grande parcela. As outras duas parlamentares, Camila Toscano e Daniella Ribeiro, como pode ser observado, sequer cogitaram, em seus pronunciamentos, defenderem tais proposituras, ao contrário, suas posturas pareceu-nos serem bastante conservadoras.

Tais resultados, enfim, nos levam a construir dois pontos que deixamos para reflexão a posteriori: primeiro, a máxima que não basta ser mulher para defender os direitos e/ou interesses da mulher e de que, no entanto, ninguém melhor que a própria mulher para defender e reivindicar seus direitos. Como resolver essa ambiguidade?

\section{REFERÊNCIAS}

ARAÚJO, Clara (2009). Gênero e acesso ao poder Legislativo no Brasil: as cotas entre as instituições e a cultura. In: Revista Brasileira de Ciência Política, n. 2, Brasília.

BARBOSA, Claudia de Faria (2008). Presença feminina na política: cidadania e os espaços "público e privado". In: GT Política e Feminismo. Coordenado por Ana Alice Costa e Maria Salete da Silva. Disponível em: www.neim.ufba.br/site/arquivos/file/politica.pdf.

BATISTA, Camila Lima (2008). Análise histórica sobre os direitos políticos das mulheres no Brasil. In: GT Política e Feminismo. Coordenado por Ana Alice Costa e Maria Salete da Silva. Disponível em: www.neim.ufba.br/site/arquivos/file/politica.pdf.

BOURDIEU, Pierre. A Dominação Masculina. 10ª edição. Bertrand Brasil: Rio de Janeiro, 2011.

COELHO, Leila Machado \& BAPTISTA, Marisa (2009). A história da inserção política da mulher no Brasil: Uma trajetória do espaço privado ao público. Psicologia Política. V. 9, n. 17.

GOMES, Joaquim B. Barbosa. Ação afirmativa e o princípio constitucional da igualdade. Rio de Janeiro: Renovar. 2001.

GROSSI, Míriam Pillar e MIGUEL, Sônia Malheiros (2001). Transformando a diferença: as mulheres na política. In: Estudos Feministas. Ano 9, 2 semestre. 
MAUSS, Marcel. Ensaio Sobre a Dádiva (1974). Forma e razão da troca nas sociedades arcaicas. Sociologia e Antropologia. V. II. São Paulo. Edusp.

MIGUEL, Luis Felipe (2001). Política de interesses, política do desvelo: representação e singularidade feminina. In: Estudos Feministas, Ano 9, 2. Semestre.

MIGUEL, Luis Felipe. BIROLI, Flávia (2011). Caleidoscópio Convexo: mulheres, política e mídia. São Paulo, Editora Unesp.

(2006). Gênero e política na mídia brasileira. Disponível em: http://www.mulheres.gov.br/assuntos/poder-e-participacao-politica/referencias/genero-emidia/generoepoliticanamidia.pdf.

MORAES, Roque. Análise de conteúdo. Revista Educação, Porto Alegre, v. 22, n. 37, p. 7-32, 1999.

PAIVA, Raquel. Política: Palavra Feminina. Rio de Janeiro: Mauad X, 2008.

PRADO, Maria Lígia. FRANCO, Stella Scatena (2013). A participação feminina no debate político brasileiro. In: PINSKY, Bassanezi. PEDRO, Joana Maria (org.) Nova história das mulheres no Brasil. São Paulo, Contexto

PINHEIRO, Luana Simões (2007). Vozes Femininas na Política: uma análise sobre mulheres parlamentares no pós-constituinte. Brasília: Secretaria Especial de Políticas para as Mulheres.

RABAY, Glória. CARVAlHO, Maria Eulina Pessoa de (2010). Mulher e Política na Paraíba: História de vida e luta. João Pessoa: Editora Universidade da UFPB.

ROSALDO, Michelli (1995). O uso e abuso da antropologia: Reflexões sobre o feminismo e o entendimento intercultural. Revista Horizontes Antropológicos - Gênero. Porto Alegre. Ano 1, $\mathrm{n}^{\circ}$ 1.

SANTOS, Ivanir dos \& MEDEIROS, Carlos Alberto. "Privilégios ameaçados". O Globo, Rio de Janeiro, 21 dezembro. 2001.

SCOTT, Joan (1996). Gênero: uma categoria útil de análise histórica. Educação e Sociedade. Porto Alegre, v. 20, n.2, p. 71-99, jun./dez.

SOARES, Vera (1998). Muitas faces do feminismo no Brasil. Disponível em: http://www2.fpa.org.br/portal/uploads/feminismobrasil.pdf.

\section{DOCUMENTOS ELETRÔNICOS}

http://g1.globo.com

http://brasil.elpais.com

http://politica.estadao.com.br

http://www.al.pb.gov.br

http://www.camara.gov.br/proposicoesWeb/prop_mostrarintegra?codteor=1349292\&filename=EM $\mathrm{A}+57 / 2015+\% 3 \mathrm{D} \% 3 \mathrm{E}+\mathrm{PEC}+182 / 2007$ 


\title{
A DISPUTE AND SUB-REPRESENTATION OF WOMEN IN POWER SPACES: THE CASE OF LEGISLATIVE ASSEMBLY PARAÍBA
}

\begin{abstract}
The advent of women's participation in politics raises some points for reflection. The trajectory faced by women in order to win the public space and allow a subordinate to the private sphere and the home, the difficulties and still faced prejudice to the institution of positions within the political practice and the ineffectiveness of the Quota Law, are some of the aspects that should be discussed when it comes to the struggle of women for positions of power. Thus, this article focuses its analysis on the reconstruction of historical and cultural journey undertaken by women regarding their participation in leadership positions and policy in structuring the political field and the Quotas Act and, above all, the analysis of a possible relationship between the "gender condition" from the parliamentary activities of the three female representatives of the Legislative Assembly of the State of Paraiba, elected in 2014. Campaign construction of the analysis proposed here was made from data collected in cyberspace, especially social networks such as Facebook and follow-up of the main stories published on the websites and local blogs referring to activities and public actions of these deputies.
\end{abstract}

Key-words: Women and Politics, Gender, Quota Law, Legislative. 